\title{
Effect of glucosamine on expression of type II collagen, matrix metalloproteinase and sirtuin genes in a human chondrocyte cell line
}

\author{
MAMORU IGARASHI $^{1}$, KOJI SAKAMOTO ${ }^{1,2}$ and ISAO NAGAOKA ${ }^{1}$ \\ ${ }^{1}$ Department of Host Defense and Biochemical Research, Graduate School of Medicine, Juntendo University, \\ Tokyo 113-8421; ${ }^{2}$ Koyo Chemical Co., Ltd., Tokyo 110-0015, Japan
}

Received April 2, 2016; Accepted December 15, 2016

DOI: $10.3892 /$ ijmm.2016.2842

\begin{abstract}
Glucosamine $(\mathrm{GlcN})$ has been widely used to treat osteoarthritis (OA) in humans. However, the effects of GlcN on genes related to cartilage metabolism are still unknown. In the present study, to elucidate the chondroprotective action of GlcN on OA, we examined the effects of GlcN $(0.1-10 \mathrm{mM})$ on the expression of the sirtuin (SIRT) genes as well as type II collagen and matrix metalloproteinases (MMPs) using a human chondrocyte cell line SW 1353. SW 1353 cells were incubated in the absence or presence of GlcN. RT-PCR analyses revealed that GlcN markedly increased the mRNA expression of type II collagen (COL2AI). By contrast, the levels of $M M P-1$ and $M M P-9$ mRNA were only slightly increased by GlcN. Furthermore, western blot analyses revealed that GlcN significantly increased the protein level of COL2A1. Importantly, GlcN enhanced the mRNA expression and protein level of SIRT1, an upstream-regulating gene of COL2A1. Moreover, a SIRT1 inhibitor suppressed GlcN-induced COL2Al gene expression. Together these observations suggest that GlcN enhances the mRNA expression and protein level of SIRT1 and its downstream gene COL2AI in chondrocytes, thereby possibly exhibiting chondroprotective action on OA.
\end{abstract}

\section{Introduction}

Osteoarthritis (OA) is the most common joint disorder among the elderly presenting with joint pain and deformities. $\mathrm{OA}$ is considered a major public health issue causing chronic disability worldwide in the increasing number of aging humans (1). OA is characterized by qualitative and quantitative changes in the architecture and composition of joint structures $(2,3)$. OA is a multifactorial disease of the cartilage, and aging is one of the

Correspondence to: Professor Isao Nagaoka, Department of Host Defense and Biochemical Research, Graduate School of Medicine, Juntendo University, 2-1-1 Hongo, Bunkyo-ku, Tokyo 113-8421, Japan E-mail: nagaokai@juntendo.ac.jp

Key words: glucosamine, type II collagen, sirtuin, matrix metalloproteinase, chondrocyte important risk factor for OA (4). However, the mechanisms, such as inflammation, apoptosis, and degradation of major extracellular matrix (ECM) components (including type II collagen and aggrecan) are commonly involved in the cartilage degradation in OA (5).

Glucosamine $(\mathrm{GlcN})$, a naturally occurring amino monosaccharide, is present in connective and cartilage tissues as a component of glycosaminoglycans (GAGs), and contributes to maintaining the strength, flexibility and elasticity of these tissues. Thus, GlcN has been widely used to treat OA for more than three decades in humans (6-9). In fact, several short-term and long-term clinical trials in OA have shown the significant symptom-modifying effect of GlcN (10-12). We previously revealed that GlcN can induce hyaluronic acid (HA) production by synovial cells and chondrocytes (13). Furthermore, the balance between the synthesis and degradation of ECM components in the cartilage is important for the maintenance of articular metabolism, and the disturbance of this balance leads to the progressive destruction of cartilage in OA (14-17). Thus, GlcN is expected to exert a protective effect on the balance between the synthesis and degradation of ECM components in the cartilage. However, the effects of GlcN on the expression of the genes related to cartilage metabolism are not fully understood.

In the present study, therefore, to further elucidate the chondroprotective action of GlcN, we examined the effect of GlcN on the expression of genes related to cartilage metabolism, such as type II collagen and the matrix metalloproteinases (MMPs).

\section{Materials and methods}

Reagents. D-Glucosamine hydrochloride (GlcN) was purchased from Wako Pure Chemical Industries, Ltd. (Osaka, Japan). Penicillin-streptomycin mixed solution, dimethyl sulfoxide (DMSO) and dithiothreitol (DTT) were purchased both from Nacalai Tesque, Inc. (Kyoto, Japan). EX527 [a sirtuin 1 (SIRT1) inhibitor] was purchased from Selleckchem (Houston, TX, USA).

Cells. Human chondrocytes (SW 1353) were purchased from the American Type Culture Collection(HTB-94, ATCC; Manassas, VA, USA). SW 1353 cells were maintained in Leibovitz's L-15 medium (Gibco-Invitrogen Life Technologies, Carlsbad, CA, 
USA) containing $10 \%$ fetal bovine serum (FBS; Biological Industries, Cromwell, CT, USA), penicillin and streptomycin at $37^{\circ} \mathrm{C}$ under a humidified atmosphere without $\mathrm{CO}_{2}$.

Semi-quantitative reverse transcription-polymerase chain reaction $(R T-P C R)$. SW 1353 cells $\left(3.0 \times 10^{6}\right.$ cells/flask) were plated into T-75 $\mathrm{cm}^{2}$ flasks (Corning Inc., Corning, NY, USA) overnight. The cells were incubated in the absence or presence of GlcN $(0.1,1$ and $10 \mathrm{mM})$ for $24 \mathrm{~h}$, or incubated with GlcN $(1 \mathrm{mM})$ in the absence or presence of EX527 $(1 \mu \mathrm{M})$ or DMSO (as a solvent) for $6 \mathrm{~h}$ (18). After incubation, the cells were washed twice with ice-cold phosphate-buffered saline (PBS; $137 \mathrm{mM} \mathrm{NaCl}, 2.7 \mathrm{mM} \mathrm{KCl}, 8.1 \mathrm{mM} \mathrm{Na}_{2} \mathrm{HPO}_{4}$, $1.5 \mathrm{mM} \mathrm{KH} \mathrm{PO}_{4}, \mathrm{pH}$ 7.4) and collected by a cell scraper (Sumitomo Bakelite Co., Ltd., Tokyo, Japan). Then, total RNA was purified using an RNeasy Plus Mini kit and QIAshredder (both from Qiagen, Hilden, Germany) by removing contaminated DNA, according to the manufacturer's instructions, and stored at $-80^{\circ} \mathrm{C}$. Reverse transcription was performed using a ReverTra Ace ${ }^{\circledR}$ (Toyobo Co., Ltd., Osaka, Japan), and PCR amplification was performed with GoTaq ${ }^{\circledR}$ Hot Start Green Master Mix (Promega, Madison, WI, USA) in a thermal cycler (GeneAmp PCR System 9700; Applied Biosystems, Foster City, CA, USA) for type II collagen (COL2A1), $M M P-1, M M P-2, M M P-9 M M P-13$, SIRT1-SIRT7 and glyceraldehyde 3-phosphate dehydrogenase $(G A P D H)$, according to the manufacturer's instructions. In brief, cDNA was synthesized by reverse transcription using total RNA (500 ng), ReverTra $A_{c e}{ }^{\circledR}$ reverse transcriptase and oligo $(\mathrm{dT})_{20}$. To discriminate mRNA-derived PCR products from genomic DNA-derived products, the intron-spanning PCR primers were used with the annealing temperature and cycle number, as shown in Table I. PCR products were resolved by $1 \%$ agarose gel electrophoresis in 1X Tris-acetate-EDTA buffer and stained with ethidium bromide. In our preliminary experiments, we tried to semi-quantitatively detect mRNA by using different cycle numbers of PCR. The results revealed that the amounts of RT-PCR products increased dependently on the cycle number. Thus, we decided to measure the mRNA levels by RT-PCR with the cycle number indicated in Table I. The expression of GAPDH was used as a standard. The detected bands were quantified using BioDoc-it Imaging System (UVP LLC, Upland, CA, USA) and quantified using Multi Gauge version 3.0 (Fujifilm, Tokyo, Japan).

Western blot analysis. SW1353 cells (3.0x10 6 cells/flask) were plated into T-75 $\mathrm{cm}^{2}$ flasks overnight. The cells were incubated in the absence or presence of $\operatorname{GlcN}(0.1,1$ and $10 \mathrm{mM})$ for $24 \mathrm{~h}$. After incubation, the cells were washed twice with ice-cold PBS and collected by a cell scraper (Sumitomo Bakelite Co., Ltd.). For the detection of COL2A1, the cells were added together with $100 \mu 1$ of RIPA buffer $[50 \mathrm{mM}$ Tris- $\mathrm{HCl} \mathrm{pH}$ 7.6, $150 \mathrm{mM} \mathrm{NaCl}, 1 \% \mathrm{NP}-40,0.5 \%$ sodium deoxycholate, $0.1 \%$ sodium dodecyl sulfate (SDS)] with a protease inhibitor (Complete Protease Inhibitor Cocktail set; Roche Diagnostics, Mannheim, Germany), sonicated (Model UD-201 ultrasonic disruptor, output $20 \mathrm{~W}$, duty 10 for 3 times; Tomy Digital Biology, Co., Ltd., Tokyo, Japan) and placed on ice for $15 \mathrm{~min}$. After centrifugation $\left(8,000 \mathrm{x} \mathrm{g}, 4^{\circ} \mathrm{C}\right.$, $15 \mathrm{~min}$ ), the supernatants were used for SDS-polyacrylamide gel electrophoresis (PAGE). For the detection of SIRT1, the cells were added together with $100 \mu 1$ of lysis buffer $(50 \mathrm{mM}$ Tris- $\mathrm{HCl} \mathrm{pH} 7.6,150 \mathrm{mM} \mathrm{NaCl}, 1 \mathrm{mM} \mathrm{MgCl} 2,1 \% \mathrm{NP}-40$, $10 \%$ glycerol, $1 \mathrm{mM}$ DTT) with a protease inhibitor (Roche Diagnostics), sonicated (Model UD-201 ultrasonic disruptor, output $20 \mathrm{~W}$, duty 10 for 5 times) and placed on ice for $15 \mathrm{~min}$. After centrifugation $\left(8000 \mathrm{x} \mathrm{g}, 4^{\circ} \mathrm{C}, 15 \mathrm{~min}\right)$, the supernatants were used for SDS-PAGE. Cell lysates (20 $\mu \mathrm{g}$ protein/lane for COL2A1 and $10 \mu \mathrm{g}$ protein/lane for SIRT1) were subjected to SDS-PAGE and transferred to polyvinylidene fluoride membranes (Immobilon-P; Millipore, Billerica, MA, USA). The membranes were blocked overnight with Blocking One (Nacalai Tesque, Inc.) at $4^{\circ} \mathrm{C}$, washed with PBS containing $0.1 \%$ Tween-20 (PBST) at room temperature, and then probed with rabbit anti-human COL2A1 antibody (sc-28887; 1,000-fold dilution) or rabbit anti-human SIRT1 antibody (sc-15404; 1,000-fold dilution) (both from Santa Cruz Biotechnology, Inc., Santa Cruz, CA, USA), followed by horseradish peroxidase (HRP)-conjugated goat anti-rabbit IgG (AQ132P; 5,000-fold dilution; Chemicon International, Inc., Temecula, CA, USA). Signals were detected with SuperSignal ${ }^{\circledR}$ West Pico Chemiluminescent Substrate (Pierce Biotechnology, Inc., Rockford, IL, USA), and quantified using LAS-3000 luminescent image analyzer and Multi Gauge (both from Fujifilm). The expression of GAPDH was analyzed with mouse anti-human GAPDH antibody (MAB374; 30,000-fold dilution; Chemicon International, Inc.) and HRP-conjugated goat anti-mouse IgG/IgM (115-035-044; 5,000-fold dilution; Jackson ImmunoResearch Laboratories, Inc., West Grove, PA, USA) as an internal standard.

Statistical analysis. Data are shown as mean \pm SD of three separate experiments, and were analyzed for significant difference by a Student's t-test in Excel analysis. Differences were considered statistically significant at $\mathrm{p}<0.05$.

\section{Results}

Effect of GlcN on the genes related to cartilage metabolism in chondrocytes. First, the effect of GlcN on the expression of genes related to cartilage metabolism, such as COL2AI and $M M P s$, was evaluated. As shown in Fig. 1, the expression of COL2A1 mRNA was significantly ( $>5$-fold) increased by $\mathrm{GlcN}(0.1,1$ and $10 \mathrm{mM})$ compared with the expression noted in the control without GlcN ( $\mathrm{p}<0.05)$. Furthermore, the expression of $M M P-1$ mRNA was significantly but only 1.2 -fold increased by GlcN $(10 \mathrm{mM})(\mathrm{p}<0.05)$. Moreover, the expression of MMP-9 mRNA was significantly but only 1.2 -fold increased by GlcN (1 and $10 \mathrm{mM}$ ). By contrast, the expression of $M M P-2$ and $M M P-13$ mRNAs was not essentially changed by GlcN, although the expression of $M M P-13$ mRNA was slightly increased without statistically significant difference.

Second, the protein level of COL2A1 was evaluated, since the expression of $C O L 2 A 1$ mRNA was greatly increased by GlcN (Fig. 1). As shown in Fig. 2, the protein level of COL2A1 was significantly ( $>2$-fold) increased by GlcN ( $1 \mathrm{mM})$ compared with this level in the control without GlcN.

Effect of GlcN on SIRT gene expression in chondrocytes. The expression of COL $2 A 1 \mathrm{mRNA}$ was significantly increased 
Table I. Gene-specific PCR primers, annealing temperature $\left({ }^{\circ} \mathrm{C}\right)$ and the cycle number for PCR.

\begin{tabular}{|c|c|c|c|c|c|}
\hline Gene & Forward primer & Reverse primer & $\begin{array}{c}\text { Annealing } \\
\text { temperature }\left({ }^{\circ} \mathrm{C}\right)\end{array}$ & Cycle nos. & Refs. \\
\hline COL2A1 & 5'-atgacaatctggctcccaacactgc-3' & 5'-gaccggccctatgtccacaccgaat-3' & 52 & 41 & $(19)$ \\
\hline$M M P-1$ & 5'-gccagatttgccaagagcaga-3' & 5'-cggcaaattcgtaagcagcttc-3' & 55 & 34 & (20) \\
\hline$M M P-2$ & 5'-ggccctgtcactcctgagat-3' & 5'-ggcatccaggttatcgggga-3' & 58 & 29 & $(21)$ \\
\hline$M M P-9$ & 5'-cggagcacggagacgggtat-3' & 5'-tgaaggggaagacgcacagc-3' & 58 & 35 & $(21)$ \\
\hline$M M P-13$ & 5'-gacttcacgatggcattgctg-3' & 5'-gcatcaacctgctgaggatgc-3' & 59 & 39 & $(22)$ \\
\hline SIRT1 & 5'-gggatggtatttatgctcgc-3' & 5'-ctatgatttgtttgatggatagttc-3' & 55 & 34 & $(23)$ \\
\hline SIRT2 & 5'-agcaaggcacccctctccacc-3' & 5'-ggtttctccctctctgttgtc-3' & 57 & 31 & $(24)$ \\
\hline SIRT3 & 5'-tgagagagtgtcgggcatccetg-3' & 5'-tcatcctatttgtctggtccatcaa-3' & 55 & 33 & $(25)$ \\
\hline SIRT4 & 5'-accctgagaaggtcaaagagttac-3' & 5'-ttccccacaatccaagcac-3' & 55 & 33 & $(26)$ \\
\hline SIRT5 & 5'-ccgagtgtgagacccggctgggca-3' & 5'-ttgtaattctcagccacaactcc-3' & 54 & 31 & $(27)$ \\
\hline SIRT6 & 5'-ccaagttcgacaccaccttt-3' & 5'-cggacgtactgcgtcttaca-3' & 55 & 31 & $(28)$ \\
\hline SIRT7 & 5'-gggagtacgtgcgggtgttcgatg-3' & 5'-ggccgccggctagggggcttggtc-3' & 60 & 33 & (27) \\
\hline$G A P D H^{\mathrm{a}}$ & 5'-accacagtccatgccatcac-3' & 5'-tccaccaccctgttgctgta-3' & 60 & 20 & \\
\hline
\end{tabular}

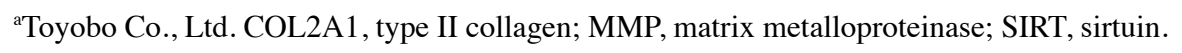
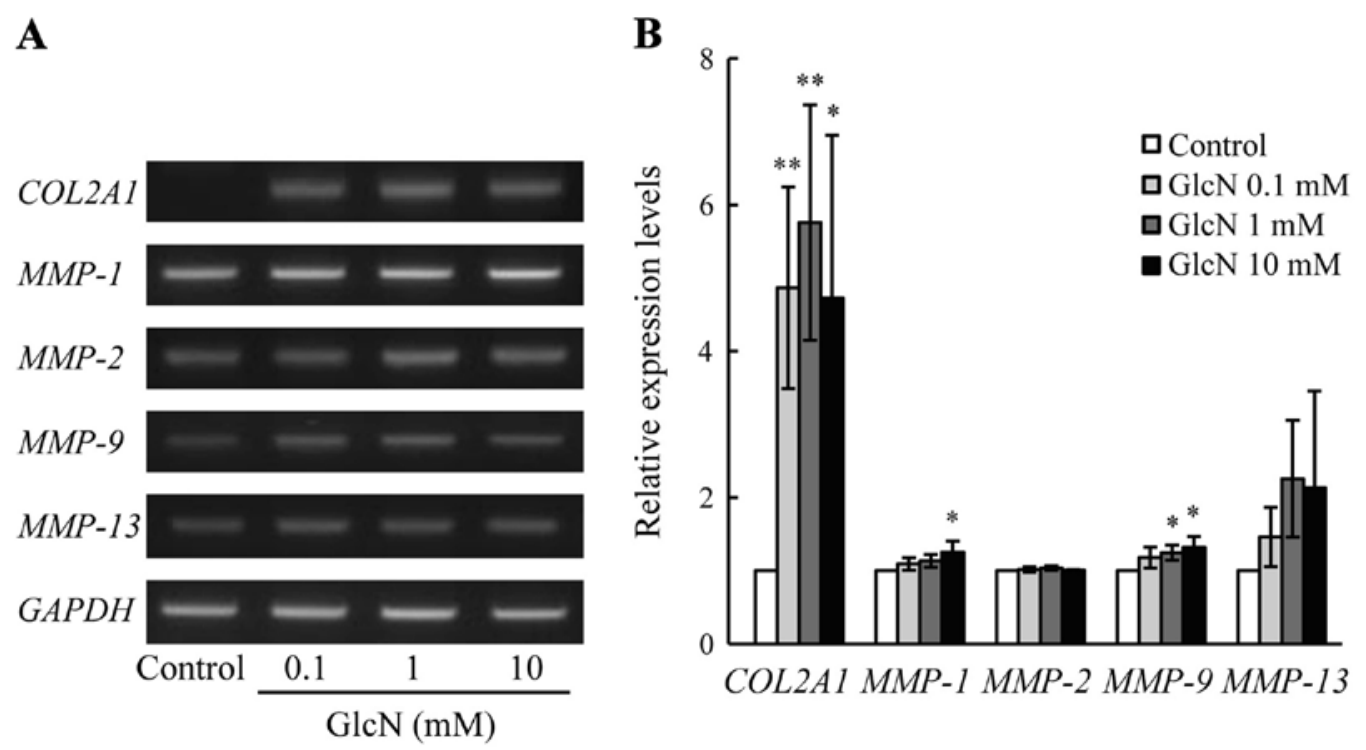

Figure 1. Effect of glucosamine (GlcN) on the mRNA expression of genes related to cartilage metabolism. Chondrocytes (SW 1353) were cultured in the absence (Control) or presence of $\mathrm{GlcN}(0.1,1$ and $10 \mathrm{mM})$ for $24 \mathrm{~h}$. After incubation, total RNA was purified, and mRNA expression of the genes related to cartilage metabolism was evaluated by RT-PCR. PCR products were resolved by $1 \%$ agarose gel electrophoresis, and stained with ethidium bromide. (A) mRNA levels of genes related to cartilage metabolism. Data represent one of three independent experiments. (B) Quantification of mRNA levels of genes related to cartilage metabolism. The GAPDH expression levels were evaluated as an internal standard. The relative expression of mRNAs for type II collagen (COL2A1) and matrix metalloproteinases (MMPs) corrected for the expression of GAPDH is expressed as a ratio to the control cells incubated without GlcN. Data represent the mean $\pm \mathrm{SD}$ of three independent experiments. Values were compared between the absence (Control) and presence of $\mathrm{GlcN}$. " $\mathrm{p}<0.05$, ${ }^{* *} \mathrm{p}<0.01$.

by GlcN (Fig. 1). Thus, the effect of GlcN on the expression of SIRTI, an upstream-regulating gene of COL2A1 (29), was evaluated. As shown in Fig. 3, the expression of SIRT1 mRNA was significantly (3- to 4 -fold) increased by GlcN $(0.1,1$ and $10 \mathrm{mM}$ ) compared with that noted in the control without GlcN (p<0.05). In humans, the SIRT gene family consists of 7 genes, SIRT1-SIRT7 (30); thus, the effect of GlcN on the expression of SIRT2-SIRT7 genes was evaluated. As shown in Fig. 3, the expression of SIRT5 mRNA was significantly but only slightly $(\sim 2$-fold) increased by GlcN $(\mathrm{p}<0.05)$. By contrast, the mRNA expression of SIRT2, SIRT3, SIRT4, SIRT6 and $S I R T 7$ was not essentially changed by GlcN. Moreover, the protein level of SIRT1 was evaluated, since the expression of SIRT1 mRNA was found to be greatly increased among the SIRT family genes by GlcN. As shown in Fig. 4, the protein level of SIRT1 was significantly (5- to 6-fold) increased by 
A

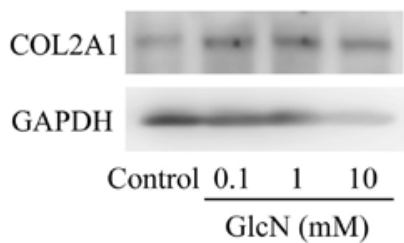

B

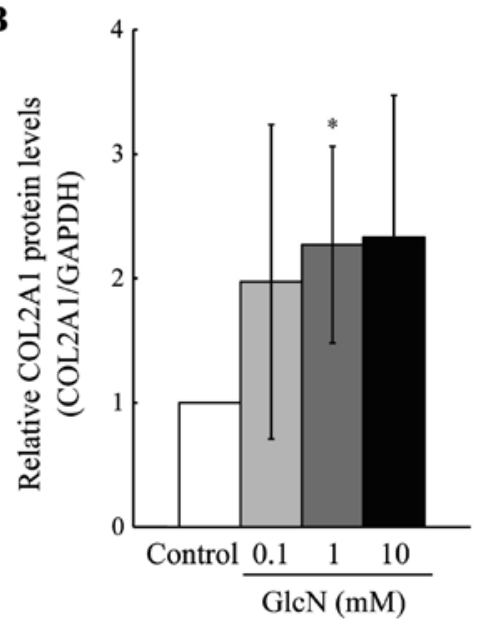

Figure 2. Effect of glucosamine $(\mathrm{GlcN})$ on the protein levels of type II collagen (COL2A1). Chondrocytes (SW 1353) were cultured in the absence (Control) or presence of $\mathrm{GlcN}(0.1,1$ and $10 \mathrm{mM})$ for $24 \mathrm{~h}$. After the incubation, total protein was extracted, and the protein levels of COL2A1 were detected by western blot analysis. (A) Protein levels of COL2A1. Data represent one of three independent experiments. (B) Quantification of COL2A1 protein levels. The protein levels of GAPDH were evaluated as an internal standard. The relative protein level of COL2A1 corrected for the level of GAPDH is expressed as a ratio to the control cells incubated without GlcN Data represent the mean $\pm \mathrm{SD}$ of three independent experiments. Values were compared between the absence (Control) and presence of GlcN. " $\mathrm{p}<0.05$.

GlcN (1 mM) compared with this level in the control without GlcN $(\mathrm{p}<0.01)$.

Effect of a SIRT1 inhibitor on COL2A1 and SIRT1 gene expression in chondrocytes. As mentioned above, COL2A1 and SIRT1 expression levels were increased by GlcN. Thus, we aimed to ascertain whether the $\mathrm{GlcN}$-induced $\mathrm{COL} 2 \mathrm{Al}$ gene expression is mediated by SIRT1 gene expression. For this purpose, the effect of EX527, a specific SIRT1 inhibitor (31), on the expression of $C O L 2 A l$ gene expression was evaluated. Importantly, the $\mathrm{GlcN}$-induced $\mathrm{COL} 2 \mathrm{Al}$ gene expression was significantly suppressed by EX527, although the GlcN-induced SIRT1 gene expression was not affected by EX527 (Fig. 5). These observations obviously indicate that the GlcN-induced COL2Al gene expression was regulated by the $S I R T 1$ gene expression.

\section{Discussion}

GlcN exhibits a symptom-modifying effect on OA (6-8), and has been used to relieve the symptoms of OA in humans (32). Previously, we demonstrated that GlcN can induce HA production by synovial cells and chondrocytes (13). However, the effects of GlcN on genes related to cartilage metabolism are not fully understood.

Collagens and proteoglycans are the major components in the ECM (33). COL2A1 is the most abundant collagen in
A

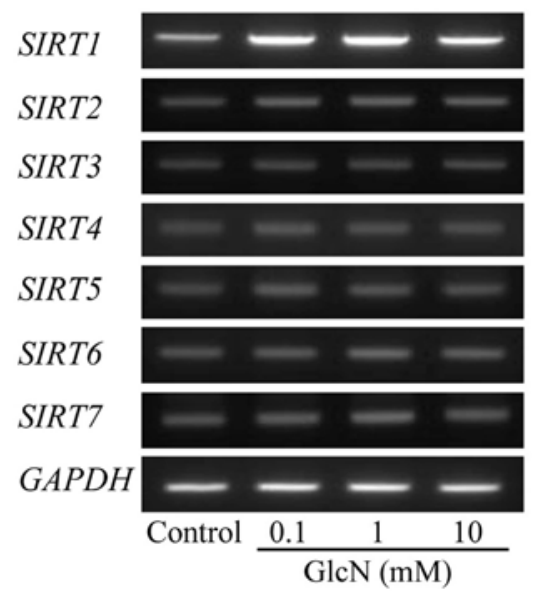

B

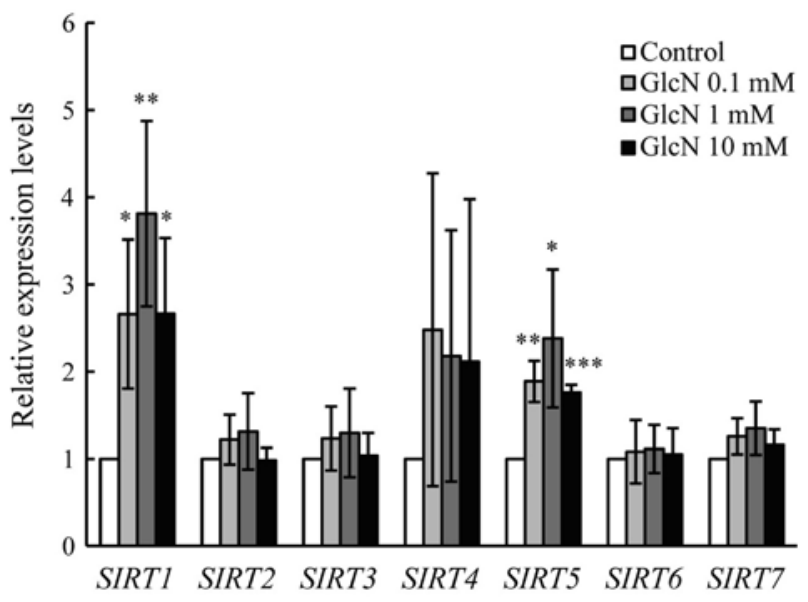

Figure 3. Effect of glucosamine $(\mathrm{GlcN})$ on the mRNA expression of sirtuins (SIRTS). Chondrocytes (SW 1353) were cultured in the absence (Control) or presence of GlcN $(0.1,1$ and $10 \mathrm{mM})$ for $24 \mathrm{~h}$. After incubation, total RNA was purified, and the expression of mRNA for SIRTs was evaluated by RT-PCR. PCR products were resolved by $1 \%$ agarose gel electrophoresis, and stained with ethidium bromide. (A) mRNA levels of SIRTs. Data represent one of three independent experiments. (B) Quantification of mRNA levels of SIRTs. The $G A P D H$ expression levels were evaluated as an internal standard. The relative expression of mRNAs for SIRT1-7 corrected for the expression of GAPDH is expressed as a ratio to control cells incubated without GlcN. Data represent the mean $\pm \mathrm{SD}$ of three independent experiments. Values were compared between the absence (Control) and presence of GlcN. ${ }^{*} \mathrm{p}<0.05,{ }^{* *} \mathrm{p}<0.01,{ }^{* * *} \mathrm{p}<0.001$.

articular cartilage, and provides cartilage tissue with tensile strength $(34,35)$. In this study, we revealed that GlcN obviously enhanced the mRNA and protein levels of COL2A1 in the chondrocytes (Figs. 1 and 2), although GlcN has been previously reported to increase type II collagen synthesis (36-39). By contrast, GlcN only slightly increased the mRNA expression of the MMPs (Fig. 1). These observations suggest that GlcN upregulates the expression of anabolic genes (such as COL2A1) rather than catoblic genes (such as MMPs), thereby possibly exhibiting chondroprotective actions on degenerative joint diseases such as OA.

SIRTl is known as an upstream-regulating gene of COL2Al in chondrocytes (29) and exerts chondroprotective action in OA (40-42). In this context, it is important to note 
A

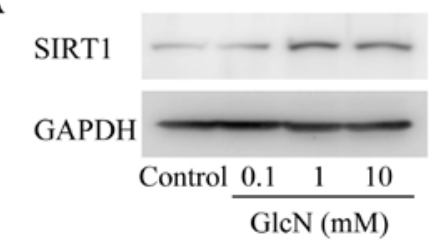

B

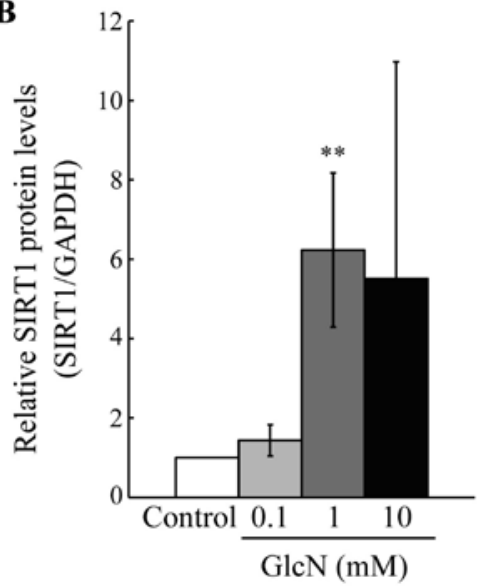

Figure 4. Effect of glucosamine $(\mathrm{GlcN})$ on the protein levels of sirtuin 1 (SIRT1). Chondrocytes (SW 1353) were cultured in the absence (Control) or presence of $\mathrm{GlcN}(0.1,1$ and $10 \mathrm{mM})$ for $24 \mathrm{~h}$. After incubation, total protein was extracted, and the protein levels of SIRT1 were detected by western blot analysis. (A) Protein levels of SIRT1. Data represent one of three independent experiments. (B) Quantification of SIRT1 protein levels. The protein levels of GAPDH were evaluated as an internal standard. The relative protein level of SIRT1 corrected for the level of GAPDH is expressed as a ratio to control cells incubated without glucosamine. Data represent the mean $\pm \mathrm{SD}$ of three independent experiments. Values were compared between the absence (Control) and presence of GlcN. ${ }^{* *} \mathrm{p}<0.01$.

that adult heterozygous Sirtl-knockout mice and chondrocyte-specific Sirt1-conditional knockout mice presented with reduced intensity of Safranin-O staining and increased OA progression compared with wild-type mice (40,41); Sirtl point mutation-knockin mice were found to exhibit OA progression (42). Furthermore, SIRT1 promotes cartilage-specific gene expression, such as COL2Al (29) in chondrocytes, and protects chondrocytes from senescence (43). Moreover, SIRT1 was found to inhibit the apoptosis of human chondrocytes $(44,45)$, whereas knockdown of SIRT1 led to osteoarthritic gene expression in human chondrocytes (46). In addition, overexpression of SIRT1 inhibited interleukin (IL)$1 \beta$ - or tumor necrosis factor (TNF)- $\alpha$-induced expression of cartilage-degrading enzymes (such as MMPs) by modulating the nuclear factor (NF)- $\kappa B$ pathway $(47,48)$. These observations suggest that SIRT1 exhibits a chondroprotective action on OA by upregulating cartilage-specific gene expression (such as $C O L 2 A 1)$ but inhibiting cartilage-degrading enzymes (such as MMPs) in chondrocytes. Notably, the present results demonstrated that GlcN markedly enhanced the mRNA and protein levels of SIRT1 as well as COL2A1 in chondrocytes among the SIRT genes examined (Figs. 3 and 4). Importantly, the GlcN-induced COL2Al gene expression was significantly suppressed by EX527, a SIRT1-specific inhibitor (Fig. 5). Together these observations suggest the possibility that GlcN exhibits protective actions on chondrocytes by upregulating COL2A1 expression via SIRT1 expression.
$\mathbf{A}$

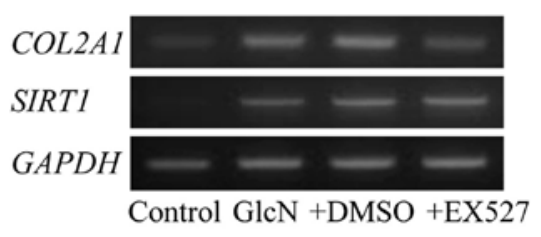

B

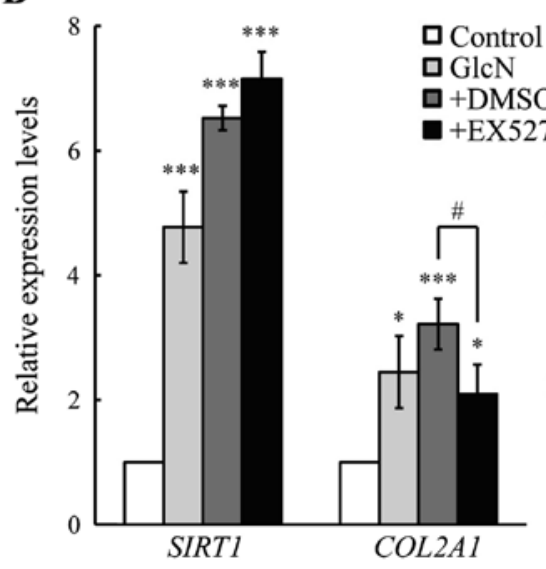

Figure 5. Effects of sirtuin 1 (SIRT1) inhibitor on glucosamine $(\mathrm{GlcN})$-induced type II collagen (COL2A1) mRNA expression. Chondrocytes (SW 1353) were cultured without or with GlcN $(1 \mathrm{mM})$ in the absence or presence of EX527 (+EX527, $1 \mu \mathrm{M})$ or DMSO (+DMSO) for $6 \mathrm{~h}$. After incubation, total RNA was purified, and the expression of mRNA for COL2A1 and SIRT1 was evaluated by RT-PCR. PCR products were resolved by $1 \%$ agarose gel electrophoresis, and stained with ethidium bromide. (A) mRNA levels of COL2A1 and SIRT1. Data represent one of three independent experiments. (B) Quantification of the mRNA levels for COL2A1 and SIRT1 genes. The $G A P D H$ expression levels were evaluated as an internal standard. The relative expression of mRNAs for SIRT1 and COL2A1 corrected for the expression of $G A P D H$ is expressed as a ratio to control cells incubated without GlcN, DMSO or EX527. Data represent the mean \pm SD of three independent experiments. Values were compared between the absence (Control) and presence of GlcN ( $\left.{ }^{*} \mathrm{p}<0.05,{ }^{* * *} \mathrm{p}<0.001\right)$ or + EX527 and +DMSO $\left({ }^{\#} \mathrm{p}<0.05\right)$.

On the other hand, it has been noted that the $O$-linked $\mathrm{N}$-acetylglucosamine $(\mathrm{O}$-GlcNAc) modification of target proteins modulates cellular functions, such as nuclear transport, transcription, translation, cell signaling, apoptosis and cell shape, and the modification is mediated via the addition of $O$-GlcNAc to the hydroxy group in a serine or threonine residue by $O$-GlcNAc transferase $(49,50)$. In this context, it has been demonstrated that several transcription factors are modified by $O$-GlcNAc, and such modification regulates their transcriptional activities of genes (51-55). Moreover, we previously reported that $O$-GlcNAc modification is increased by GlcN in endothelial cells and synovial cells (56-58). Thus, elucidation of the involvement of GlcN-mediated $O$-GlcNAc modification in the transcriptional regulation of SIRT1 in chondrocytes in the future is warranted.

In conclusion, the present study revealed that GlcN upregulates COL2A1 and SIRT1 expression in chondrocytes. Moreover, a SIRT1 inhibitor suppressed the GlcN-induced upregulation of COL2A1 gene expression. Together these observations suggest that GlcN enhances the mRNA expression and protein level of SIRT1 and its downstream gene COL2Al in chondrocytes, thereby possibly exhibiting chondroprotective action. However, the present study has a limitation, as we only evaluated the effects of GlcN on the expression of COL2A1, MMPs and SIRTs using a chondro- 
cyte cell line SW 1353. Thus, it remains to be elucidated whether GlcN modulates the expression of these genes in articular chondrocytes.

\section{Acknowledgements}

This study was supported by the Institute for Environmental and Gender-Specific Medicine, Juntendo University and JSPS KAKENHI (grant no. 23580183).

\section{References}

1. Hunter DJ and Felson DT: Osteoarthritis. BMJ 332: 639-642, 2006

2. Gabriel SE, Crowson CS, Campion ME and O'Fallon WM: Direct medical costs unique to people with arthritis. J Rheumatol 24: 719-725, 1997.

3. March LM and Bachmeier CJ: Economics of osteoarthritis: a global perspective. Baillieres Clin Rheumatol 11: 817-834, 1997.

4. Loeser RF: Age-related changes in the musculoskeletal system and the development of osteoarthritis. Clin Geriatr Med 26: 371-386, 2010

5. Goldring MB: The role of cytokines as inflammatory mediators in osteoarthritis: lessons from animal models. Connect Tissue Res 40: 1-11, 1999.

6. Crolle G and D'Este E: Glucosamine sulphate for the management of arthrosis: a controlled clinical investigation. Curr Med Res Opin 7: 104-109, 1980.

7. Drovanti A, Bignamini AA and Rovati AL: Therapeutic activity of oral glucosamine sulfate in osteoarthrosis: a placebo-controlled double-blind investigation. Clin Ther 3: 260-272, 1980.

8. Tapadinhas MJ, Rivera IC and Bignamini AA: Oral glucosamine sulphate in the management of arthrosis: report on a multi-centre open investigation in Portugal. Pharmatherapeutica 3: 157-168, 1982.

9. Lopes Vaz A: Double-blind clinical evaluation of the relative efficacy of ibuprofen and glucosamine sulphate in the management of osteoarthrosis of the knee in out-patients. Curr Med Res Opin 8: 145-149, 1982.

10. McAlindon TE, LaValley MP, Gulin JP and Felson DT: Glucosamine and chondroitin for treatment of osteoarthritis: a systematic quality assessment and meta-analysis. JAMA 283: 1469-1475, 2000.

11. Reginster JY, Deroisy R, Rovati LC, Lee RL, Lejeune E, Bruyere O, Giacovelli G, Henrotin Y, Dacre JE and Gossett C: Long-term effects of glucosamine sulphate on osteoarthritis progression: a randomised, placebo-controlled clinical trial. Lancet 357: 251-256, 2001.

12. Pavelká K, Gatterová J, Olejarová M, Machacek S, Giacovelli G and Rovati LC: Glucosamine sulfate use and delay of progression of knee osteoarthritis: a 3-year, randomized, placebo-controlled, double-blind study. Arch Intern Med 162: 2113-2123, 2002.

13. Igarashi M, Kaga I, Takamori Y, Sakamoto K, Miyazawa K and Nagaoka I: Effects of glucosamine derivatives and uronic acids on the production of glycosaminoglycans by human synovial cells and chondrocytes. Int J Mol Med 27: 821-827, 2011.

14. Loeser RF: Molecular mechanisms of cartilage destruction: mechanics, inflammatory mediators, and aging collide. Arthritis Rheum 54: 1357-1360, 2006.

15. Abramson SB, Attur M and Yazici Y: Prospects for disease modification in osteoarthritis. Nat Clin Pract Rheumatol 2: 304-312, 2006

16. Goldring MB and Goldring SR: Osteoarthritis. J Cell Physiol 213: 626-634, 2007.

17. Attur M, Krasnokutsky-Samuels S, Samuels J and Abramson SB Prognostic biomarkers in osteoarthritis. Curr Opin Rheumatol 25: 136-144, 2013.

18. Li Y, Tsun A, Gao Z, Han Z, Gao Y, Li Z, Lin F, Wang Y, Wei G, Yao Z, et al: $60-\mathrm{kDa}$ Tat-interactive protein (TIP60) positively regulates Th-inducing $\mathrm{POK}$ (ThPOK)-mediated repression of eomesodermin in human $\mathrm{CD}^{+} \mathrm{T}$ cells. J Biol Chem 288 15537-15546, 2013.

19. Hattori T, Kubota S, Yutani Y, Fujisawa T, Nakanishi T, Takahashi $\mathrm{K}$ and Takigawa M: Change in cellular localization of a rheumatoid arthritis-related antigen (RA-A47) with downregulation upon stimulation by inflammatory cytokines in chondrocytes. J Cell Physiol 186: 268-281, 2001.
20. Neumann C, Yu A, Welge-Lüssen U, Lütjen-Drecoll E and Birke M: The effect of TGF-beta2 on elastin, type VI collagen, and components of the proteolytic degradation system in human optic nerve astrocytes. Invest Ophthalmol Vis Sci 49: 1464-1472, 2008.

21. Kim SO and Kim MR: [6]-Gingerol prevents disassembly of cell junctions and activities of MMPs in invasive human pancreas cancer cells through ERK/NF- $\kappa \mathrm{B} /$ Snail signal transduction pathway. Evid Based Complement Alternat Med 2013: 761852, 2013

22. Liacini A, Sylvester J, Li WQ, Huang W, Dehnade F, Ahmad M and Zafarullah M: Induction of matrix metalloproteinase-13 gene expression by TNF-alpha is mediated by MAP kinases, AP-1, and NF-kappaB transcription factors in articular chondrocytes. Exp Cell Res 288: 208-217, 2003.

23. Shah ZH, Ahmed SU, Ford JR, Allison SJ, Knight JRP and Milner J: A deacetylase-deficient SIRT1 variant opposes full-length SIRT1 in regulating tumor suppressor p53 and governs expression of cancer-related genes. Mol Cell Biol 32: 704-716, 2012.

24. Ji S, Doucette JR and Nazarali AJ: Sirt2 is a novel in vivo downstream target of $\mathrm{Nkx} 2.2$ and enhances oligodendroglial cell differentiation. J Mol Cell Biol 3: 351-359, 2011.

25. Grubisha O, Rafty LA, Takanishi CL, Xu X, Tong L, Perraud AL, Scharenberg AM and Denu JM: Metabolite of SIR2 reaction modulates TRPM2 ion channel. J Biol Chem 281: 14057-14065, 2006.

26. Song R, Xu W, Chen Y, Li Z, Zeng Y and Fu Y: The expression of sirtuins 1 and 4 in peripheral blood leukocytes from patients with type 2 diabetes. Eur J Histochem 55: e10, 2011.

27. Orecchia A, Scarponi C, Di Felice F, Cesarini E, Avitabile S, Mai A, Mauro ML, Sirri V, Zambruno G, Albanesi C, et al: Sirtinol treatment reduces inflammation in human dermal microvascular endothelial cells. PLoS One 6: e24307, 2011.

28. Kanfi Y, Shalman R, Peshti V, Pilosof SN, Gozlan YM, Pearson KJ, Lerrer B, Moazed D, Marine JC, de Cabo R, et al: Regulation of SIRT6 protein levels by nutrient availability. FEBS Lett 582: 543-548, 2008.

29. Dvir-Ginzberg M, Gagarina V, Lee EJ and Hall DJ: Regulation of cartilage-specific gene expression in human chondrocytes by SirT1 and nicotinamide phosphoribosyltransferase. J Biol Chem 283: 36300-36310, 2008.

30. Gray SG and Ekström TJ: The human histone deacetylase family. Exp Cell Res 262: 75-83, 2001.

31. Gertz M, Fischer F, Nguyen GTT, Lakshminarasimhan M, Schutkowski M, Weyand $M$ and Steegborn C: Ex-527 inhibits sirtuins by exploiting their unique $\mathrm{NAD}^{+}$-dependent deacetylation mechanism. Proc Natl Acad Sci USA 110: E2772-E2781, 2013.

32. Nagaoka I, Igarashi $\mathrm{M}$ and Sakamoto K: Biological activities of glucosamine and its related substances. Adv Food Nutr Res 65: 337-352, 2012.

33. Bhosale AM and Richardson JB: Articular cartilage: structure, injuries and review of management. Br Med Bull 87: 77-95, 2008.

34. Eyre DR: Collagens and cartilage matrix homeostasis. Clin Orthop Relat Res 427 (Suppl): S118-S122, 2004.

35. Eyre DR, Weis MA and Wu JJ: Articular cartilage collagen: an irreplaceable framework? Eur Cell Mater 12: 57-63, 2006.

36. Block JA, Oegema TR, Sandy JD and Plaas A: The effects of oral glucosamine on joint health: is a change in research approach needed? Osteoarthritis Cartilage 18: 5-11, 2010.

37. Varghese S, Theprungsirikul P, Sahani S, Hwang N, Yarema KJ and Elisseeff JH: Glucosamine modulates chondrocyte proliferation, matrix synthesis, and gene expression. Osteoarthritis Cartilage 15: 59-68, 2007.

38. Derfoul A, Miyoshi AD, Freeman DE and Tuan RS: Glucosamine promotes chondrogenic phenotype in both chondrocytes and mesenchymal stem cells and inhibits MMP-13 expression and matrix degradation. Osteoarthritis Cartilage 15: 646-655, 2007.

39. Stoppoloni D, Politi L, Leopizzi M, Gaetani S, Guazzo R, Basciani S, Moreschini O, De Santi M, Scandurra R and Scotto d'Abusco A: Effect of glucosamine and its peptidyl-derivative on the production of extracellular matrix components by human primary chondrocytes. Osteoarthritis Cartilage 23: 103-113, 2015.

40. Gabay O, Oppenhiemer H, Meir H, Zaal K, Sanchez C and Dvir-Ginzberg M: Increased apoptotic chondrocytes in articular cartilage from adult heterozygous SirT1 mice. Ann Rheum Dis 71: 613-616, 2012. 
41. Matsuzaki T, Matsushita T, Takayama K, Matsumoto T, Nishida K, Kuroda R and Kurosaka M: Disruption of Sirt1 in chondrocytes causes accelerated progression of osteoarthritis under mechanical stress and during ageing in mice. Ann Rheum Dis 73: 1397-1404, 2014.

42. Gabay O, Sanchez C, Dvir-Ginzberg M, Gagarina V, Zaal KJ, Song Y, He XH and McBurney MW: Sirtuin 1 enzymatic activity is required for cartilage homeostasis in vivo in a mouse model. Arthritis Rheum 65: 159-166, 2013.

43. Hong EH, Lee SJ, Kim JS, Lee KH, Um HD, Kim JH, Kim SJ, Kim JI and Hwang SG: Ionizing radiation induces cellular senescence of articular chondrocytes via negative regulation of SIRT1 by p38 kinase. J Biol Chem 285: 1283-1295, 2010.

44. Takayama K, Ishida K, Matsushita T, Fujita N, Hayashi S, Sasaki K, Tei K, Kubo S, Matsumoto T, Fujioka H, et al: SIRT1 regulation of apoptosis of human chondrocytes. Arthritis Rheum 60: 2731-2740, 2009.

45. Gagarina V, Gabay O, Dvir-Ginzberg M, Lee EJ, Brady JK, Quon MJ and Hall DJ: SirT1 enhances survival of human osteoarthritic chondrocytes by repressing protein tyrosine phosphatase 1B and activating the insulin-like growth factor receptor pathway. Arthritis Rheum 62: 1383-1392, 2010.

46. Fujita N, Matsushita T, Ishida K, Kubo S, Matsumoto T, Takayama K, Kurosaka M and Kuroda R: Potential involvement of SIRT1 in the pathogenesis of osteoarthritis through the modulation of chondrocyte gene expressions. J Orthop Res 29: 511-515, 2011.

47. Moon MH, Jeong JK, Lee YJ, Seol JW, Jackson CJ and Park SY: SIRT1, a class III histone deacetylase, regulates TNF- $\alpha$-induced inflammation in human chondrocytes. Osteoarthritis Cartilage 21: 470-480, 2013.

48. Matsushita T, Sasaki H, Takayama K, Ishida K, Matsumoto T, Kubo S, Matsuzaki T, Nishida K, Kurosaka M and Kuroda R: The overexpression of SIRT1 inhibited osteoarthritic gene expression changes induced by interleukin-1 $\beta$ in human chondrocytes. J Orthop Res 31: 531-537, 2013.
49. Wells L, Whelan SA and Hart GW: O-GlcNAc: a regulatory post-translational modification. Biochem Biophys Res Commun 302: 435-441, 2003.

50. Love DC and Hanover JA: The hexosamine signaling pathway: deciphering the 'O-GlcNAc code'. Sci STKE 2005: re13, 2005.

51. Chou TY, Dang CV and Hart GW: Glycosylation of the c-Myc transactivation domain. Proc Natl Acad Sci USA 92: 4417-4421, 1995.

52. Han I and Kudlow JE: Reduced O glycosylation of Sp1 is associated with increased proteasome susceptibility. Mol Cell Biol 17: 2550-2558, 1997.

53. Jiang MS and Hart GW: A subpopulation of estrogen receptors are modified by O-linked $\mathrm{N}$-acetylglucosamine. J Biol Chem 272: 2421-2428, 1997.

54. Yang WH, Kim JE, Nam HW, Ju JW, Kim HS, Kim YS and Cho JW: Modification of p53 with O-linked $\mathrm{N}$-acetylglucosamine regulates p53 activity and stability. Nat Cell Biol 8: 1074-1083, 2006.

55. Fujiki R, Hashiba W, Sekine H, Yokoyama A, Chikanishi T, Ito S, Imai Y, Kim J, He HH, Igarashi K, et al: GlcNAcylation of histone H2B facilitates its monoubiquitination. Nature 480: 557-560, 2011.

56. Ju Y, Hua J, Sakamoto K, Ogawa H and Nagaoka I: Glucosamine, a naturally occurring amino monosaccharide modulates LL-37-induced endothelial cell activation. Int J Mol Med 22: 657-662, 2008

57. Ju Y, Hua J, Sakamoto K, Ogawa $\mathrm{H}$ and Nagaoka I: Modulation of TNF-alpha-induced endothelial cell activation by glucosamine, a naturally occurring amino monosaccharide. Int J Mol Med 22: 809-815, 2008.

58. Someya A, Sakamoto K and Nagaoka I: Glucosamine induces the O-N-acetylglucosamine modification of transcription factor Sp1. Glucosamine Res 9: 48-52, 2013. 